\title{
The application of legislative frameworks for the management of medical records in Limpopo Province, South Africa
}

Information Development

$1-13$

(C) The Author(s) 2018

Reprints and permission:

sagepub.co.uk/journalsPermissions.nav DOI: 10.1 I77/02666669|8772006 journals.sagepub.com/home/idv (S)AGE

\author{
Ngoako Marutha \\ University of South Africa
}

\begin{abstract}
Medical records management needs to be governed using a legal framework to avoid records being lost, modified, altered, misfiled and/or damaged, since that may result in a struggle to locate them and wasting time. Medical records management, like any other field, has to be guided by a sound legislative framework. The application of legislation in the management of medical records can help safeguard privacy and confidentiality and curb the loss, modification, alteration, damage and misfiling of records. The study sought to assess the extent to which public hospitals in the Limpopo Province, South Africa apply legislation in the management of medical records. Quantitative data were collected using questionnaires completed by records management staff members in the hospitals of Limpopo. This study applied a quantitative research methodology and a survey research design. The study revealed that legal prescripts were not appropriately followed in the healthcare institutions due to a lack of fundamental resources. The study recommended, among other things, the provision of adequate resources and the appointment of suitably qualified records managers and staff or the development of staff capacity to ensure that appropriate legal frameworks are implemented adequately.
\end{abstract}

\section{Keywords}

legislation, Limpopo Province, public hospitals, records management, South Africa

Submitted: 2 March, 2018; Accepted: 23 March, 2018.

\section{Introduction}

Legislative frameworks are at the heart of the achievement of business goals in all business sectors, the health sector included. "Any improvement in the management of records has to be done in full cognisance that records are generated in an organisational setting and based on a national legislative and regulatory framework" (Katuu and Van der Walt 2016). Due to the inappropriate implementation of relevant legislative prescripts, medical records management in healthcare institutions is usually executed unproductively (Erasmus 2013; Marutha 2011; Marutha and Ngulube 2012). For instance, non-compliance with legislative frameworks leads to inappropriate medical records management, which also causes difficulties for healthcare institutions in their attempt to produce quality data for creating knowledge to support organisational decision making and problem solving (Anova Health Institute 2012). When legislative frameworks are not properly implemented, organisations may be unable to satisfy clients' requests for records (Maponya 2013:6; Marutha and Ngulube 2012:39; Monama 2013:5). If records are poorly managed, institutions may also be unable to improve healthcare service delivery promptly through monitoring and evaluation, since that depends on the information contained in the records.

Many countries - if not all - have developed and introduced legislative prescripts to govern and provide guidance on how records produced during different functional activities may be managed and retained, including those relating to the healthcare function (Marutha 2016; 2011). For example, the

Corresponding author:

Dr Marutha Ngoako, Department of Information Science, University of South Africa, Pretoria, South Africa.

Email: emarutns@unisa.ac.za 
United Kingdom (UK) developed their legislation and records management toolkits based on International Organisation for Standardisation (ISO) standards to improve their records management as required for citizens' right of access to information (McLeod, Childs and Heaford 2007:217). Nengomasha (2013:7-9) recommends that sub-Saharan countries also need to develop records management working toolkits. On the other side, the USA has developed legislation to govern and enforce proper recordkeeping after serious scandals (McLeod, Childs and Heaford 2007:217).

Many African countries have legislative frameworks in place that may be used for management of records. However, they are struggling with the correct implementation to ensure the best practices in many business operational strategies or programmes, including records management programmes (Abbot 2007:7; Nengomasha 2013:3; Ngoepe 2014:1; Ngoepe 2012:140; Ngoepe and Van der Walt 2010:88). Existing records management legislation in African countries does not address records management issues comprehensively (Asogwa, 2012). In addition, in African countries, existing records management legislation is not being enforced (Abbot 2007:7; Ngoepe 2014:1; Asogwa 2012). This poses a very serious challenge, since in any organisation or state, laws need to be created to govern all records management business activities (Nengomasha 2013:5; Ndenje-Sichalwe, Ngulube and Stilwell 2011:268). Healthcare organisations need the legislation to regulate healthcare records management (Lott 1997: iv; Nengomasha 2013:3). Sub-Saharan African countries are negatively affected by weak records management legislation (Asogwa (2012: 201-202; Ngoepe 2014:10; 2008:111)

Healthcare legislative prescripts need to address medical records management issues (Lott, 1997: v; Boonstra and Broekhuis, 2010:11). According to Lott (1997: v) legislative frameworks should cover issues such as medical records accessibility, security, confidentiality and disposal of such healthcare records and information. He further states that if these issues are not addressed, healthcare institutions end up relying on guidelines from other bodies. This was the state of affairs in Saskatchewan, Canada (Lott 1997: v).

Limpopo is one of the nine provinces in the Republic of South Africa. The Limpopo Provincial Department of Health comprises a total of 40 hospitals providing healthcare services to the province (Marutha, 2016; 2011). In the process of delivering healthcare services, numerous records are generated and preserved for different purposes. Healthcare institutions use such records for patients' medical histories, medical transactions, litigations responses, audit requests and citizen information access. The South African government has developed legislative frameworks for healthcare services to adopt and use in developing policies, procedural manuals and other tools necessary for managing records.

\section{Literature review}

Several scholars have conducted studies investigating the legislative framework guiding records management in the public sector in South Africa (Ngoepe 2017; Katuu 2016; Ngoepe 2016; Ngoepe and Saurombe 2016; Katuu and Van der Walt 2016; Ngoepe and Makhubela 2015; Ngoepe and Makhura 2008). However, these studies did not specifically focus on the application of legislative frameworks in managing medical records in Limpopo Province. Studies by Katuu (2016) and Katuu and Van der Walt (2016) addressed issues relating to healthcare records and legislative frameworks very broadly, focusing on the whole of South Africa. Katuu's (2016) study used literature review to discuss healthcare records management and legislative frameworks in relation to the eHealth Strategy, the implementation of electronic document and records management systems (EDRMS) and the utility of maturity models. Katuu and Van der Walt (2016) used literature review and 22 interview participants from healthcare sectors in public and private academic and research institutions to study the management of healthcare records and legislative frameworks in the whole of South Africa. Focusing specifically on all 40 public hospitals in Limpopo, this study intensively assessed compliance with relevant legal frameworks in the management of medical records.

It is imperative for any country to develop and implement a legislative framework that will assist in guiding healthcare processes (Katuu 2015:94; Cullinan 2006:4), including archiving and management of health records. The colonial regime failed to establish an effective archives and records management legislative framework and related infrastructure to govern proper archive and records management in African countries until independence (Asogwa 2012:199). There was no adequate legislation and infrastructure (Asogwa 2012:199) or policies, as alluded to by Boonstra and Broekhuis (2010:11). 
The significance of an archives and records management law in any country or organisation cannot be overemphasised. Ismail and Jamaludin (2009:136137) and Ndenje-Sichalwe et al. (2011:268) underscore that these laws are made to ensure mandatory establishment of a sound organisational records management framework for any organisational business transaction. The records management and archive law should govern how records should be created, kept and maintained for future organisational and individual employees' accountability (Ismail and Jamaludin 2009:136-137; Ndenje-Sichalwe et al., 2011:268). The manner in which records are captured, created, transmitted, used, stored, indexed, retrieved, controlled, retained and preserved should comply with legislation and standards (Chachage and Ngulube 2006:10; Ndenje-Sichalwe et al., 2011:268).

It is therefore the records manager's responsibility to ensure that records management operations are conducted in compliance with appropriate prescripts and organisational guidelines. The records system should comply with the current business requirements, as well as with regulatory environment and community expectations (ISO 15489-12001). The records creators should be made aware of the impact of these requirements on their business actions. The records system should be regularly assessed to check if it still complies with the requirements. The assessment activities and results should also be documented and properly preserved as evidence of the assessment (ISO 15489-12001). Moreq2 (2008:42) also attests that the establishment of ERMS guiding documents, like policies, needs laws and regulations like "data security law and archival law and industrial regulations".

Asogwa (2012:207) and Ndenje-Sichalwe et al. (2011:268) suggested that in most African countries, legislative frameworks are not updated regularly or when the need arises. This results in the creation, management, use and preservation of recorded information conducted according to legislation that is not up-to-date and not in line with the current records management technology. For instance, in most African countries the scope of archival laws covers basic models of paper-based records archiving and the archival responsibilities of an institution. These dated laws inhibit many archival institutions when it comes to managing electronic records. Due to these dated laws 'in Africa and other developing countries', archival institutions experience many difficulties in managing records effectively (Asogwa 2012:207;
Ndenje-Sichalwe et al., 2011:268). For instance, in most African countries there is no lawful definition of records, electronic records are not admissible in legal proceedings in court and existing laws describe archival institutions only as archival records custodians (Asogwa 2012:207). Asogwa (2012:207) argues as follows:

In Africa there are no laws or legislation on electronic records and electronic archives management, and therefore it is useless to manage these records without procedural and legal laws since they are not fully recognized in law courts as legal document because of their propensity for alteration at whims (Asogwa 2012:207).

Decman and Vintar (2013:407) argue that inadequate legislation exists for records management in public administration, looking at the new changes, developments and ways of doing things in different environments. There is a need for the public sector to review legislation on a regular basis or when the situation requires it. For instance, implementation of records management preservation solutions such as the central repository solution should coincide with the creation of acts and regulations to ensure proper control over the management of records in the network and in remote storage areas (Decman and Vintar 2013:417). Lott (1997: vi) and Asogwa (2012:209) emphasise that there are still many gaps in legislative prescripts due to the fast advance of technology. Legislative prescripts need to be reviewed and improved from time to time in relation to the current situation and technological requirements. Healthcare professionals and records management professionals need to embark on lifelong learning as things change or improve over time. This situation is not exclusive to medical records management (Asogwa 2012:206-209).

\section{South African legislation}

South Africa has introduced several legislative frameworks that govern the proper management of medical records. These include the National Archives and Records Service of South Africa Act (No. 43 of 1996) and Limpopo Provincial Archives Act (No. 5 of 2001), the National Health Act (No. 61 of 2003), Promotion of Access to Information Act (No. 2 of 2000) (PAIA), Electronic Communication and Transaction Act (No. 25 of 2002), Public Finance Management Act (Act No.1 of 1999), 
Protection of Personal Information Act (Act No.4 of 2013), Copyright Act (Act No.98 of 1978), Protection of State Information Bill (2010) and the Constitution (Act 108 of 1996).

The Constitution serves as "the foundational law in the country" (Katuu 2015:92), since it covers almost all the other legislative frameworks. The Constitution also emphasises issues of providing accurate and accessible information to ensure accountability and transparency of the public administration.

The purpose of the National Archives and Records Service of South Africa Act (No. 43 of 1996) was to "provide for a National Archives and Record Service; the proper management and care of the records of governmental bodies; and the preservation and use of a national archival heritage and related matters" as also elaborated on by Katuu (2015:107) and Chaterera et al. (2014:368). The Limpopo Provincial Archives Act (No.5 of 2001) was introduced with the same purpose of governing the management of records and archives in Limpopo. The South African national archivist and the Limpopo provincial archivist are mandated by law to fully take responsibility for ensuring that public records are properly managed in the custody of government bodies (National Archives and Records Service of South Africa Act (No. 43 of 1996: section 13(1); Limpopo Provincial Archives Act (No. 5 of 2001 Section 13(1); Ngoepe 2014:2; Chaterera et al., 2014:369).

Decisions pertaining to records management in government bodies are subject to approval by the National Archivist as an indication that $\mathrm{s} / \mathrm{he}$ is in charge (National Archives and Records Service of South Africa Act, No. 43 of 1996: section 13(1); Limpopo Provincial Archives Act (No.5 of 2001 section 13(1)). Government bodies must get authorisation from the National/Provincial Archivist on matters pertaining to the management of records (Ngoepe 2014:3; National Archives and Records Service of South Africa Act (No. 43 of 1996); Limpopo Provincial Archives Act (No.5 of 2001)). Legislation gives the National/Provincial Archivist the power to authorise or approve government bodies' records filing systems/classification systems, the conversion of records to microfilm or electronic formats and ways of managing the electronic system. They also mandate the National/Provincial archivist to conduct inspections of records held by government bodies, and to issue records management directives and instructions to government bodies from time to time (National Archives and Records Service of
South Africa Act (No. 43 of 1996); Limpopo Provincial Archives Act (No. 5 of 2001)).

The other legislative framework related to medical records management is the National Health Act (No.61 of 2003), as also mentioned by Katuu (2015:108). The National Health Act was introduced into the South African healthcare sector to "provide a framework for a structured uniform health system within the Republic, taking into account the obligations imposed by the Constitution and other laws on the national, provincial and local governments with regard to health services; and to provide for matters connected therewith". Section 13 of the Act addresses issues of "obligation to keep record" of the health establishment. It stipulates that the head of a healthcare establishment must ensure that health records are created and maintained in line with the National Archives of South Africa Act, 1996 (Act No. 43 of 1996) and the Promotion of Access to Information Act, 2000 (Act No. 2 of 2000) to ensure proper healthcare service continuity. Section 14 of the National Health Act deals with issues of confidentiality of information contained in the healthcare records, and stipulates that people are prohibited from disclosure of information relating to "patients health status, treatment or stay in a health establishment". The disclosure can only be legally allowed with written user consent, law enforcement or a court order or if "nondisclosure of the information represents a serious threat to public health".

Section 15 of the National Health Act deals with issues of access to health records and stipulates that a "health worker or any health care provider that has access to the health records of a user may disclose such personal information to any other person" such as coworkers for lawful purposes as required by the scope and course of the duties in favour of the user. Section 16 governs "access to health records by healthcare provider" and stipulates that the healthcare provider may be authorised by the user to examine the user's health records for treatment. Authorisation for study and research may be given by the user, the head of the healthcare establishment and the health research ethics committee. If health records do not contain user identity information, authorisation will not be required. Section 17(1) of the National Health Act deals the "protection of health records". These stipulations were also fully discussed by Katuu (2015:106-108).

Section 17 (2) of the National Health Act stipulates that it is a chargeable offence for any person to commit the following actions on the patients' records, among others: 
- falsify any record by adding or deleting or changing any information contained in that record;

- create, change or destroy a record without authority to do so;

- fail to create or change a record when properly required to do so;

- provide false information with the intent that it be included in a record without authority;

- copy any part of a record without authority;

- connect the personal identification elements of a user's record with any element of that record that concerns the user's condition, treatment or history;

- gain unauthorised access to a record or recordkeeping system;

- connect any part of a computer or other electronic system on which records are kept to any other computer or other electronic system; or any terminal or other installation connected without authority;

- modify or impair the operation of any part of the operating system of a computer or other electronic system on which a user's records are kept; or

- modify or impair the operation of any part of the programme used to record, store, retrieve or display information on a computer or other electronic system on which a user's records are kept.

Other legislation that affects records management in South Africa is the Promotion of Access to Information Act (PAIA) (No 2 of 2000). PAIA was introduced to "give effect to the constitutional right of access to any information held by the State and any information that is held by another person and that is required for the exercise or protection of any rights" as also discussed by Katuu (2015). Section 11 (1) to (3) is about the "right of access to records of public bodies". It stipulates that the information requester must not be denied access to information as long as $\mathrm{s} /$ he properly followed the information access procedure as guided by PAIA and that no denial of access should be based on the requester's reasons or on the information officer's suspicion of what might be the reason for requesting the records.

South Africa also introduced the Electronic Communication and Transaction Act (ECTA) (No. 25 of 2002) to, among other purposes, facilitate and regulate communication and transaction of an electronic format and medium and to simplify implementation of the national electronic service delivery strategy. Part One of the Act deals with issues of "legal requirements for data messages". From section 11 to 17 , the Act gives directives for issues relating to, among others, legal recognition for data messages, written information, electronic signature, originality of information or record, admissibility and evidential weight of data message, retention and production of documents or information. The other related act is the Public Finance Management Act (Act No.1 of 1999), which was introduced to regulate financial management and prevent corruption by ensuring the proper management of financial resources. Section 36(2) stipulates that the head of department (HOD) of a constitutional institution is an accounting officer charged with the accountability to keep full and proper records of the financial affairs of the department in accordance with prescribed norms and standards.

There are other acts relating to the safety, security and privacy of records. The Protection of Personal Information Act (Act No. 4 of 2013) was introduced to promote the protection of personal information processed by public and private bodies, provide minimum requirements for processing of personal information, provide the rights of persons regarding unsolicited electronic communication and automated decision making, and regulate the flow of personal information across the borders of the Republic of South Africa. It touches on issues like lawful processing of personal information; exclusion for journalistic, literary or artistic purposes; personal information processing limitations; retention and restriction of records; security safeguards, processing of special personal information; prior authority and transfer of personal information outside the borders of the country.

The Protection of State Information Bill (B6-2010) was introduced to protect certain state information from alteration, loss or destruction or unlawful disclosure; to regulate the manner in which state information may be protected; and to repeal the Protection of Information Act, 1982. It is concerned with issues such as the transfer of public records to the National Archives, releasing classified information to the public, receiving state information unlawfully, disclosing classified information, destroying or altering valuable information and protecting state information in court. The Copyright Act (Act No. 98 of 1978) was introduced to regulate issues relating to copyright. It touches on matters relating to copyright in original works, infringement of copyright and remedies, and copyright tribunal. 
Table I. Fundamental legislative framework governing medical records in South Africa $(\mathrm{N}=217)$.

Copyright Act, Act No.98 of 1978.

Protection of Personal Information Act, Act No. 4 of 2013. National Archives of South Africa Act, Act No. 43 of 1996. Public Finance Management Act, Act No.I of 1999.

Promotion of Access to Information Act, Act No. 2 of 2000. Limpopo Provincial Archives Act, Act No. 5 of 2001.

Electronic Communication and Transaction Act, Act No. 25 of 2002.

National Health Act, Act No. $6 \mathrm{I}$ of 2003.

Protection of State Information Bill, B6-20I0.

This study was focused on the legislative frameworks that are fundamentally concerned with medical records management, as shown in Table 1.

\section{Research problem}

Even though South Africa has a sound records management legislative framework, health institutions in the Limpopo Province appear to be inefficient in managing medical records (Marutha 2011; 2016), because medical records management in the provincial healthcare institutions is not executed properly as guided by these legislative prescripts (Erasmus 2013:2; Marutha 2011:189-204; Marutha and Ngulube 2012:39). Retrieving improperly filed records usually results in patients waiting too long before receiving the necessary healthcare service. This negatively affects patients, as hospitals take too long to locate records (Maponya 2013:6; Marutha and Ngulube 2012:39; Monama 2013:5).

\section{Research purpose}

The study sought to assess the extent to which public hospitals in the Limpopo Province, South Africa, apply legislation for the management of medical records.

\section{Research objective}

The objectives of this study were as follows:

- To identify legal frameworks applied in the management of medical records in hospitals in the Limpopo Province.

- To determine the application of legislation in the management of medical records in the Limpopo Province.

- To make recommendations for the application of legislation in the management of medical records.

\section{Research methodology}

The study applied a quantitative research methodology, an exploratory survey research design, stratified random sampling and the questionnaire research method. The reason for these choices was the large size of the population and the fact that it was rather dispersed geographically with many strata. The researcher wanted to cover a reliable sample that could be used to generalize the empirical results. Furthermore, a very limited range of data was collected using observation of the condition of records management and analysis of legislative documents to triangulate with the questionnaire data.

The target population in this study included records management personnel in all 40 hospitals in the Limpopo Province, since the records management personnel are assigned the duty and responsibility for managing records and making sure that records in the hospital are available, accessible, protected, reliable and authentic at all times. In framing the sampling of this study for questionnaire data collection, the researcher arranged a list of all categories of the identified population of the study. All records management officials on post levels 4 to 12 were listed, based on staff establishment spreadsheets according to their districts, hospitals and posts levels in the province.

The population of the study was sampled using the Human Resource (HR) staff establishment spreadsheet, which facilitated a random selection of individual participants. The sample frame was used to stratify and randomly select employees from different post levels in the records management unit of each hospital per district, who eventually participated in this study.

The total population identified from all the 40 hospitals in five districts of Limpopo Province of South Africa was 622, from which a sample of $49 \%$ (306) was drawn, to which a response rate of $71 \%$ (217) was obtained. The sample size confidence level was confirmed to be more than $95 \%$ and the margin of error was $4 \%$, according to the Raosoft sample size calculator which also recommended a sample size of 306 out of the total population of 622 , and which the researcher accepted.

The researcher supplemented the questionnaire data with observations about the state of records management in each hospital and analysis of the appropriate legislative frameworks relevant for management of medical records (document analysis). 
Table 2. Respondents per work positions.

\begin{tabular}{lcc}
\hline & \multicolumn{2}{c}{ Respondents } \\
\cline { 2 - 3 } Respondents work positions & $\%$ & Frequency \\
\hline Managers & $0.5 \%$ & 1 \\
Deputy managers & $3.2 \%$ & 7 \\
Senior administrative officers & $5.5 \%$ & 12 \\
Administrative officers & $6.9 \%$ & 15 \\
Chief registry clerks & $10.1 \%$ & 22 \\
Senior registry clerks & $6.5 \%$ & 14 \\
Registry clerks & $37.3 \%$ & 81 \\
Other positions such as patients' & $30.0 \%$ & 65 \\
$\quad$ administration clerks. & & \\
\hline
\end{tabular}

During the observation process, interviews were used to clarify some of the situations under observation with the official taking the researcher through the observation process.

\section{Findings}

This section will focus on presenting the findings of the study on medical records management legal frameworks in the public healthcare institutions. The same data will be discussed in the next section under discussion of the findings. This study relied on respondents who were expected to be professionals in the field of records management, since every employee, from the registry clerk to the most senior employees, is expected to have skills and competencies in archives and records management. The profile of the sample is presented in Table 2 .

The sample was drawn from all 40 hospitals in different districts of Limpopo Province, namely: 8 hospitals in Mopani district, 9 hospitals in Capricorn district, 7 hospitals in Sekhukhune district, 8 hospital in Vhembes district and 8 hospitals in the Waterberg district.

\section{South African legal frameworks used for management of medical records}

The study established the relevant legal and regulatory frameworks that guide the development of the records management programme infrastructure. This was done by requesting respondents to identify the South African legal and regulatory frameworks. The findings of this study are shown in Table 3 .

Other legislation identified by respondents as useful in records management is listed in Table 4.
Table 3. Relevant legal and regulatory frameworks that guide the development of the records management programme infrastructure $(\mathrm{N}=2 \mid 7)$.

\begin{tabular}{lcc}
\hline & \multicolumn{2}{c}{ Respondents } \\
\cline { 2 - 3 } & $\%$ & Frequency \\
\hline Legislative frameworks & $56.7 \%$ & 123 \\
\hline $\begin{array}{l}\text { Constitution of the Republic of South } \\
\text { Africa (Act No. I08 of 1996) }\end{array}$ & & \\
$\begin{array}{l}\text { National Health Act (Act No. 6I of } \\
\text { 2003) }\end{array}$ & $39.6 \%$ & 86 \\
$\begin{array}{l}\text { Northern Province Health Services Act } \\
\quad \text { Act No. 1998) }\end{array}$ & $26.3 \%$ & 57 \\
$\begin{array}{l}\text { National Archives and Records Service } \\
\text { of South Africa Act (Act No. 43 of }\end{array}$ & & \\
$\quad$ 1996) \\
$\begin{array}{l}\text { Northern Province Archives Act (Act } \\
\quad \text { No. } 5 \text { of 200I) }\end{array}$ & $36.4 \%$ & 79 \\
$\begin{array}{l}\text { Promotion of Access to Information } \\
\text { Act (Act No. 2 of 2000) }\end{array}$ & $63.1 \%$ & 137 \\
$\begin{array}{l}\text { Promotion of Administrative Justice } \\
\text { Act ( Act No.3 of 2000) }\end{array}$ & $42.9 \%$ & 93 \\
$\begin{array}{l}\text { Public Service Act (Act No. 103 of } \\
\text { 1994) }\end{array}$ & $17.5 \%$ & 38 \\
\begin{tabular}{l} 
Public Service Regulation 200I \\
\hline
\end{tabular} & $15.2 \%$ & 33 \\
\hline
\end{tabular}

The researcher asked whether respondents knew and understood the relevant legislative frameworks governing records management, In response, 76.5\% (166) of respondents said 'Yes', $14.7 \%$ (32) said 'No, and $8.8 \%$ (19) did not respond to the question and, therefore, the study concluded they did not know. Table 5 presents a full report.

Document analysis revealed through inspection reports that institutions had records managementrelated legislative frameworks, policies and procedures available in their institutions. The only challenge that was revealed by the interview was that "most of the officials in the institutions have not mastered the contents of the legislative framework and do not understand them", as one participant stated during observation.

\section{Application of the legislative framework in managing medical records}

The researcher asked from respondents the extent of the use of legislative frameworks in their healthcare institution. Legislative frameworks were used for policy development (70\%: 152), decision making and problem solving $(74.2 \%$ : 161), adopting a records management framework and e-system (59\%: 128), 
Table 4. Other useful legislations concerned with proper records management in South Africa $(\mathrm{N}=217)$.

\begin{tabular}{|c|c|c|}
\hline \multirow[b]{2}{*}{ Legislative frameworks } & \multicolumn{2}{|c|}{ Respondents } \\
\hline & $\%$ & Frequency \\
\hline $\begin{array}{l}\text { Basic Conditions of Employment Act } \\
\text { (Act No. } 75 \text { of 1997) }\end{array}$ & $19,4 \%$ & 42 \\
\hline $\begin{array}{l}\text { Skills Development Act (Act No. } 31 \text { of } \\
\text { 2003) }\end{array}$ & $7,8 \%$ & 17 \\
\hline $\begin{array}{l}\text { Employment Equity Act (Act No. } 55 \text { of } \\
\text { 1998) }\end{array}$ & $16,6 \%$ & 36 \\
\hline $\begin{array}{l}\text { National Health Act (Act No. } 55 \text { of } \\
\text { 1997) }\end{array}$ & $28,6 \%$ & 62 \\
\hline $\begin{array}{l}\text { The Public Finance Management Act } \\
\text { (Act No. I of } 1999 \text { as amended) }\end{array}$ & $19,4 \%$ & 42 \\
\hline $\begin{array}{l}\text { Protection of Information Act (Act No. } \\
84 \text { of 1984) }\end{array}$ & $35,9 \%$ & 78 \\
\hline $\begin{array}{l}\text { Protection of Personal Information Act } \\
\text { (Act No. } 4 \text { of 20I3) }\end{array}$ & $31,8 \%$ & 69 \\
\hline Limpopo Information Security Policy & $12,4 \%$ & 27 \\
\hline $\begin{array}{l}\text { Electronic Communication and } \\
\text { Transactions Act (Act No. } 25 \text { of 2005) }\end{array}$ & $32,7 \%$ & 71 \\
\hline $\begin{array}{l}\text { Minimum Information Security } \\
\text { Standards }\end{array}$ & $65,4 \%$ & 142 \\
\hline $\begin{array}{l}\text { Labour Relations Act (Act No. } 42 \text { of } \\
\text { 1995) }\end{array}$ & $5,5 \%$ & 12 \\
\hline
\end{tabular}

Table 5. Knowledge and understanding of legislative framework governing records management $(\mathrm{N}=217)$.

\begin{tabular}{lcc}
\hline & \multicolumn{2}{c}{ Respondents } \\
\cline { 2 - 3 } Responses & $\%$ & Frequency \\
\hline Yes & $76.5 \%$ & 166 \\
No & $14.7 \%$ & 32 \\
No response & $8.8 \%$ & 19 \\
\hline
\end{tabular}

referencing during policy implementation $(65.4 \%$ : $142)$, and $(72.4 \%: 157)$ specified training staff in records management. The interviews revealed that records management officials did not understand the content or stipulations of the legislative framework related to records management. Instead, they studied the names of relevant acts and regulations. This report is illustrated in Figure 1.

\section{Legal frameworks and medical records management infrastructure}

According to section 13 (4) of the National Archives of South Africa Act (No. 43 of 1996), which deals with the management of public records, "the National Archivist may from time to time issue directives and instructions, which shall not be inconsistent with the regulations, as to the management and care of public records in the custody of governmental bodies". The National Archivist of South Africa has issued many directives and instructions; some of them in the form of policy manuals. These directives, instructions and policy manuals deal with, among other things, conditions of records storage, shelving equipment and facilities, administrative resources for records, training of staff, structuring of the records management programme or unit, security measures, electronic records, migration from one system or format to another, records safety and security, disaster management, and a number of other things that need to be implemented. These directives, instructions and policy manuals are issued in terms of the Act. They must be implemented, since failure to implement is failure to comply with the Act. Similar to organisational policy, that is regulated by means of a procedure manual, an Act may never be specific to details and it is always regulated with directives, instructions and policy manuals.

The purpose of this section was to study the current fundamental records management affairs in the healthcare institutions. It revealed whether the hospitals were complying with different legislative frameworks or not. Compliance with legal stipulations will result in proper recordkeeping and purpose-built infrastructure. Asked about the medical records storage capacity, $13.8 \%$ (30) of respondents agreed that it was adequate, $75.1 \%$ (163) disagreed and $11.1 \%$ (24) were unsure. It was observed that there was a great shortage of recordkeeping space.

A total of $14.8 \%$ (32) respondents agreed that the shelving equipment and facilities were adequate; $75.1 \%$ (163) disagreed and $10.1 \%$ (22) were unsure. According to observation, some files were kept on the floor between shelves due to shortage of space for more shelves. In assessing records administration resources, $26.3 \%$ (57) agreed that they were adequate, $71.9 \%$ (156) disagreed and $1.8 \%$ (4) were unsure. The interview and observation process reported a great shortage of records management-related resources in the majority of hospitals such as boxes, file covers, markers and other related resources, due to a limited budget allocation for medical records management. "There are many things that are not possible to achieve since we lack basic working resources including stationery, boxes and markers" said one interview 


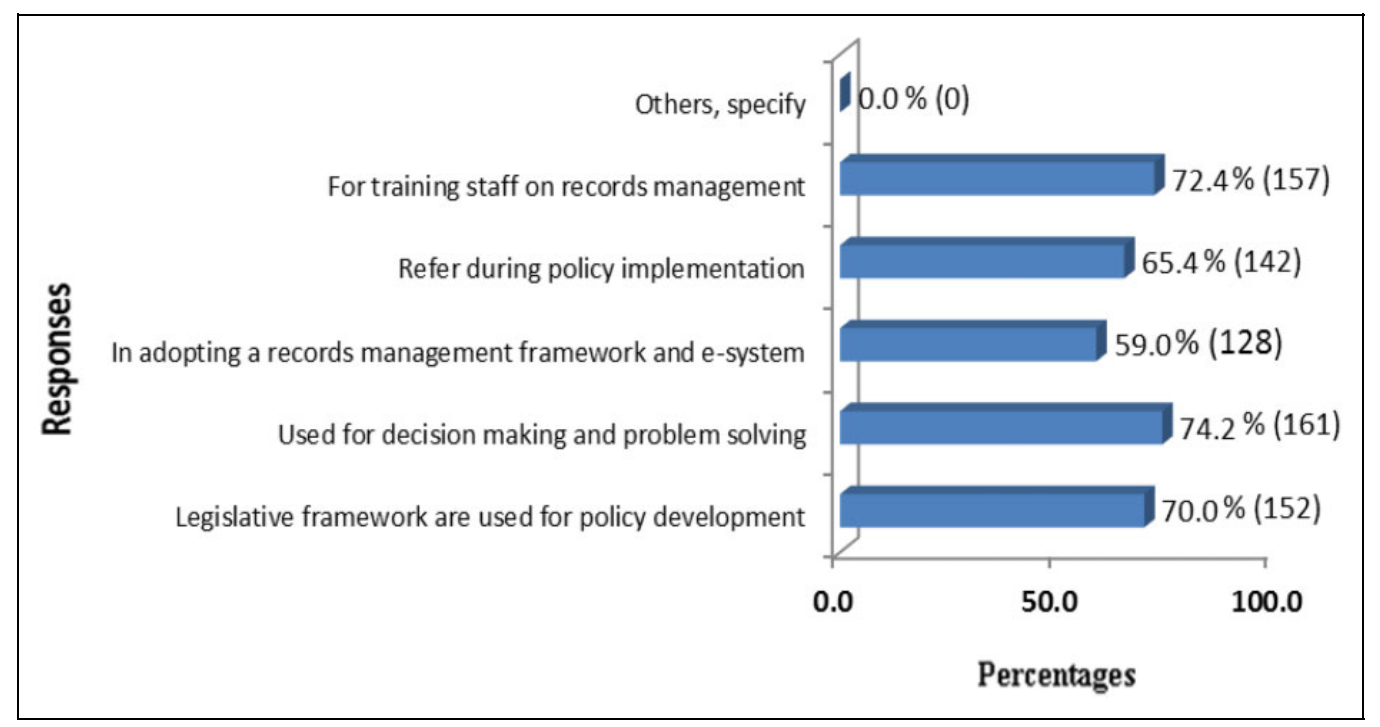

Figure I. Application of the legislative framework in governing medical records management $(\mathrm{N}=2$ I7).

participant. See details about the summarised findings presented in Table 6 .

The other assessment was based on whether disaster preventive measures were in place and effective. Of all the respondents, $10.1 \%$ (22) agreed that they were in place and were effective, $70.5 \%$ (153) disagreed and $19.4 \%$ (42) were unsure. The researcher also observed a shortage of the key records security measures such as burglar-proofing equipment; firefighting equipment was stored in the corridors, water taps and pipes crossed the records storage areas, there was a lack of smoke and water detectors, nonfunctional or non-existent ventilation control equipment, including air-conditioners and irregular fumigation. Looking at the availability of a records backup system, $6.5 \%$ (14) respondents agreed that it was available, $71.4 \%$ (155) disagreed and $22.1 \%$ (48) were unsure. Observation and interviews also confirmed a lack of a backup system for medical records. "Our medical records are not duplicated and this means if they get damaged they will not be replaced," said one interview participant.

As far as electronic recordkeeping technology was concerned, $16.2 \%$ (35) agreed that it was adequate and effective, $67.7 \%$ (147) disagreed and $16.1 \%$ (35) were unsure. System analysis revealed that the system was only used to capture demographic and billing data of patients, not prescriptions, treatments, diagnoses and many others. Regarding the statement that the records storage ventilation system was effective, $12.5 \%$ (27) respondents agreed, $77 \%$ (167) disagreed and $10.6 \%$ (23) were unsure. Observation
Table 6. Effectiveness of the current medical records management infrastructure in terms of legal and regulatory requirements $(\mathrm{N}=217)$.

\begin{tabular}{|c|c|c|c|c|}
\hline $\begin{array}{l}\text { Current medical records } \\
\text { management infrastructure } \\
\text { effectiveness }\end{array}$ & & Agree & Disagree & Unsure \\
\hline $\begin{array}{l}\text { The medical records } \\
\text { storage capacity is } \\
\text { adequate. }\end{array}$ & $\begin{array}{l}\text { No. } \\
\%\end{array}$ & $\begin{array}{l}30 \\
13.8\end{array}$ & $\begin{array}{l}163 \\
75.1\end{array}$ & $\begin{array}{l}24 \\
11.1\end{array}$ \\
\hline $\begin{array}{l}\text { Shelving equipment and } \\
\text { facilities are adequate. }\end{array}$ & $\begin{array}{l}\text { No. } \\
\%\end{array}$ & $\begin{array}{l}32 \\
14.8\end{array}$ & $\begin{array}{l}163 \\
75.1\end{array}$ & $\begin{array}{l}22 \\
10.1\end{array}$ \\
\hline $\begin{array}{l}\text { Records administration } \\
\text { resources are adequate }\end{array}$ & $\begin{array}{l}\text { No. } \\
\%\end{array}$ & $\begin{array}{l}57 \\
26.3\end{array}$ & $\begin{array}{l}156 \\
71.9\end{array}$ & $\begin{array}{l}4 \\
1.8\end{array}$ \\
\hline $\begin{array}{l}\text { Disaster preventive } \\
\text { measures are in place } \\
\text { and effective. }\end{array}$ & $\begin{array}{l}\text { No. } \\
\%\end{array}$ & $\begin{array}{l}22 \\
10.1\end{array}$ & $\begin{array}{l}153 \\
70.5\end{array}$ & $\begin{array}{l}42 \\
19.4\end{array}$ \\
\hline $\begin{array}{l}\text { Records backup system is } \\
\text { available. }\end{array}$ & $\begin{array}{l}\text { No. } \\
\%\end{array}$ & $\begin{array}{l}14 \\
6.5\end{array}$ & $\begin{array}{l}155 \\
71.4\end{array}$ & $\begin{array}{l}48 \\
22.1\end{array}$ \\
\hline $\begin{array}{l}\text { Electronic recordkeeping } \\
\text { technology is adequate } \\
\text { and effective. }\end{array}$ & $\begin{array}{l}\text { No. } \\
\%\end{array}$ & $\begin{array}{l}35 \\
16.2\end{array}$ & $\begin{array}{l}147 \\
67.7\end{array}$ & $\begin{array}{l}35 \\
16.1\end{array}$ \\
\hline $\begin{array}{l}\text { Records storage } \\
\text { ventilation system is } \\
\text { effective. }\end{array}$ & $\begin{array}{l}\text { No. } \\
\%\end{array}$ & $\begin{array}{l}27 \\
12.5\end{array}$ & $\begin{array}{r}167 \\
77\end{array}$ & $\begin{array}{l}23 \\
10.5\end{array}$ \\
\hline $\begin{array}{l}\text { Records access control } \\
\text { measures are effective. }\end{array}$ & $\begin{array}{l}\text { No. } \\
\%\end{array}$ & $\begin{array}{l}58 \\
26.7\end{array}$ & $\begin{array}{c}145 \\
66.8\end{array}$ & $\begin{array}{l}14 \\
6.5\end{array}$ \\
\hline $\begin{array}{l}\text { Records movement } \\
\text { tracking system is } \\
\text { effective. }\end{array}$ & $\begin{array}{l}\text { No. } \\
\%\end{array}$ & $\begin{array}{l}40 \\
18.4\end{array}$ & $\begin{array}{l}166 \\
76.5\end{array}$ & $\begin{array}{l}11 \\
5.1\end{array}$ \\
\hline $\begin{array}{l}\text { Records safety and } \\
\text { security measures are } \\
\text { adequate and effective. }\end{array}$ & $\begin{array}{l}\text { No. } \\
\%\end{array}$ & $\begin{array}{l}80 \\
36.9\end{array}$ & $\begin{array}{l}133 \\
61.3\end{array}$ & $\begin{array}{l}4 \\
1.8\end{array}$ \\
\hline
\end{tabular}


revealed that in most of, if not all, institutions, air conditioners were either not available or were not functional or not set to the correct temperature. It was further revealed that officials often sit and do their registry administrative work inside the records storage areas due to a shortage of working offices or working space. For more summarised details see Table 6.

Regarding the statement that records access control measures were effective, $26.7 \%$ (58) respondents agreed, $66.8 \%$ (145) disagreed and $6.5 \%$ (14) were unsure. It was observed that access control was not effective, as patients were able to move around carrying their files on the healthcare service workflow, and revenue personnel responsible for billing patients were able to access the storage space and issue files to external clients such as lawyers. Out of all the respondents, $18.4 \%$ (40) agreed and $76.5 \%$ (166) disagreed with the statement that the records movement tracking system was effective and $5.1 \%$ (11) were unsure. The records movement tracking system was, however, not effective as established by observation and explained through interviews: "our institution experienced cases of missing files too frequently and, sometimes, we experience difficulty in locating certain files of records" said one interview participant. When checking whether records safety and security measures were adequate and effective, $36.9 \%$ (80) agreed, $61.3 \%$ (133) disagreed and $1.8 \%$ (4) were unsure. As found during observation and interviews, safety and security measures were not adequate, since there were insufficient fundamental resources for records security. The details are presented in Table 6 .

\section{Discussion}

This section sets out the findings of the study based on the objectives and presented data.

\section{South African legal frameworks used to guide the management of medical records}

Legislative frameworks assist in guiding healthcare processes. This implies that all countries should develop these frameworks and stipulate the requirement for records management in the functions they govern, as underscored by Katuu (2015:94) and Cullinan (2006:4). It is evident that even though the colonial regime has failed to establish effective archives and a records management legislative framework (Asogwa 2012:199) up to now, South Africa has developed many such frameworks for use by government and private bodies. Hence, the healthcare institutions in Limpopo have used several legal and regulatory frameworks as a guideline for the establishment of a records management infrastructure. Although the policies and procedure were not properly implemented due to a lack of financial and human resources, these policies and procedures were developed in line with legal and regulatory frameworks.

\section{Knowledge of the legislative framework governing records management in South Africa}

In most government bodies, records management strategies, policies and procedure either did not exist or were not implemented, as also attested to by Ngoepe (2014:10). This is a very serious drawback to the government body. It is imperative for any country to develop and implement a legislative framework that will assist in guiding healthcare processes (Katuu 2015:94; Cullinan 2006:4), such as archiving and management of health records, and qualified records managers must be appointed and be provided with appropriate support to implement such a legislative framework. South Africa developed an extensive legislative framework guiding proper records management. The officials in the institutions knew about the existence of these frameworks, which was confirmed by $76.5 \%$ (166) of respondents. To support that, institutions had records management-related legislative frameworks, policies and procedures available in their institutions. Yet some of the officials in the institutions did not know or understand the contents of these legislative frameworks, which may also hinder proper implementation even if the resources may be made available.

\section{Application of the legislative framework in governing medical records management}

In many African countries, relevant and proper records management legislation is not enforced, which is a sign of poor planning or lack of planning in records management programme implementation (Abbot 2007:7; Ngoepe 2014:1; Asogwa 2012: 201202). Legislative frameworks need to be applied in different activities of records management, including medical records - they are mandatory and not a choice. In the Limpopo hospitals, the legislative frameworks were used for different purposes, such as developing policies, making decisions and solving problems, adopting records management frameworks 
and e-systems, referencing during policy implementation and staff training on records management. Nevertheless, there is a need for training relating to legislative frameworks governing records management since the majority of records management officials do not understand the content or stipulations of the legislative frameworks; instead, they merely learn the names of applicable acts and regulations, which is not effective. The organisation may opt for in-house training depending on existing capacity or outsource the training service to consultants or institutions of higher learning should they not have the capacity to conduct it themselves.

\section{The South African legal frameworks and the state of medical records management infrastructure}

Legislation plays an important role in any organisational activity, therefore also in records management activities. Since every function or activity produces records, which are to be used for different purposes such as audit and investigations or inspections, the legislation that governs such function also stipulates expectations relating to recordkeeping. The laws are supposed to be made available to ensure mandatory establishment of a sound organisational records management framework for any organisational business transaction. The records management and archive law should give direction on how records should be created, kept and maintained for future organisational and individual employees' accountability (Ismail and Jamaludin 2009:136-137; Ndenje-Sichalwe et al., 2011:268). The manner in which records are captured, created, transmitted, used, stored, indexed, retrieved, controlled, retained and preserved has to comply with legislation and standards (Chachage and Ngulube 2006:10; Ndenje-Sichalwe et al., 2011:268). Failure to conduct these activities in accordance with legislation or National Archives directives and instructions constitutes non-compliance or deviation from the legislative requirements. Act requires all government bodies to manage their records as directed by the National Archivist, failure of which is a deviation from the mandate of parliament issued through that legislative framework.

Focusing on the situation in Limpopo Province, although the legislative framework is available in South Africa, the records management infrastructure in Limpopo healthcare institutions was not fully in line with the South African legal and regulatory frameworks requirements, although most of the respondents said that it was. This was observed and confirmed by interview participants. The signs of non-compliance observed included water taps and pipes crossing some records storages, no security measures like water and smoke detectors, lack of firefighting measures, lack of ventilation control tools like air conditioners in most records preservation custodies, and buildings or storages seemingly not built for recordkeeping purposes. These factors pose a high security threat to medical records, which thus sacrifice the integrity, accuracy, reliability and authenticity of the records. Although the medical records management policy and procedure manual gave a proper mandate and guidelines in line with the legislative framework governing records management, the healthcare institutions did not comply with most of the requirements as stipulated in the guidelines. This implies that healthcare institutions in the Limpopo Province deviate from parliamentary legislative mandates.

\section{Conclusion and recommendations of the study}

In conclusion, it can be stated that relevant legislative frameworks relating to records management, including medical records management, are available and known to records management officials in the Limpopo hospitals, though further training appears to be required to ensure intensive understanding for appropriate implementation. Based on the findings of this study there are key inhibitors to proper implementation of or compliance with this legislative framework such as lack of key resources like human and financial resources, as presented in Table 6. One of the recommendations of this study is that hospitals should ensure that more than $75 \%$, if not all, of positions established are filled, in particular records manager posts, to ensure proper implementation of legal frameworks. The records manager, with adequate resources, must be able to implement the medical records management strategies to ensure that records are adequately captured, created, transmitted, used, stored, indexed, retrieved, controlled, retained and preserved in compliance with legislation, as also alluded to by Chachage and Ngulube (2006:10) and NdenjeSichalwe et al. (2011:268). The heads of the healthcare institutions must provide the necessary resources, as guided by the medical records management legislations and other National Archivist guideline documents. In doing this, they will ensure that the records 
management infrastructure in the Limpopo healthcare institutions is fully implemented in line with the requirements of the South African legal and regulatory frameworks. For instance, the head of the institution should provide records storage that is free from water taps and pipes crossing records storage spaces, adequate security measures such as water and smoke detectors, adequate firefighting precautionary measures, adequate ventilation control tools, such as air conditioners, and records storages that are purpose built for recordkeeping. As part of legislative requirements, the organisational disaster management plan also needs to be implemented and the heads of the institutions must provide the necessary resources and other appropriate support. The healthcare institutions must use legislative frameworks as a guideline for different records management actions such as developing policies, making decisions and solving problems, adopting records management frameworks, and developing e-systems, as a source of reference during policy implementation and records management training for staff. This will help them to align their records management activities with the relevant legal and regulatory prescripts.

\section{References}

Abbot B (2007) A South African call for an integrated perspective! ESARBICA Newsletter 20:2-6.

Anova Health Institute (2012) Anova's Limpopo team improves data quality, 31 July, Available at: http:// www.anovahealth.co.za/news/entry/anovas_limpopo_ team_improves_data_quality/(Accessed 15 July 2013).

Asogwa BE (2012) The challenge of managing electronic records in developing countries: implications for records managers in sub-Saharan Africa. Records Management Journal (22)3:198-211.

Boonstra A and Broekhuis M (2010) Barriers to the acceptance of electronic medical records by physicians from systematic review to taxonomy and interventions $B M C$ Health Service Research: 1-17.

Chachage B and Ngulube P (2006) Management of business records in Tanzania: an exploratory case study of selected companies. South African Journal of Information Management 8(3):1-18.

Chaterera F, Ngulube P and Rodrigues A (2014) Records surveys in support of a framework for managing public records in Zimbabwe. Information Development (30)4: 366-377.

Cullinan K (2006) Health Services in South Africa: A basic introduction. Available: http://www.health-e.org.za/wpcontent/uploads/2013/04/Health_services_briefing_ doc.pdf (Accessed 20 January 2016).
Decman M and Vintar M (2013) A possible solution for digital preservation of e-government: A centralised repository within a cloud computing framework. Aslib Proceedings: New Information Perspectives (65)4: 406-424.

Erasmus N (2013) Health dept fails to reach $56 \%$ of targets. Review Weekend 24-25 October: 2.

International Organization for Standardization (ISO) 15489 (2001) Information and Documentation - Records Management. Part 1. General. Geneva, ISO.

Ismail A and Jamaludin A (2009) Towards establishing a framework for managing trusted records in the electronic environment. Records Management Journal (19)2:134-145.

Katuu S (2016) Transforming South Africa's health sector: The eHealth Strategy, the implementation of electronic document and records management systems (EDRMS) and the utility of maturity models. Journal of Science and Technology Policy Management (7)3: 330-345.

Katuu SA (2015) Managing records in South African public health care institutions - a critical analysis, $\mathrm{PhD}$ thesis. University of South Africa, Pretoria.

Katuu S and Van der Walt T (2016) Assessing the legislative and regulatory framework supporting the management of records in South Africa's public health sector. South African Journal of Information Management (18) 1 .

Klug H (2012) Access to medicine and the transformation of the South African state. Transnational Legal Ordering and State Change. Shaffer G. C. Cambridge, UK, Cambridge University Press: 148-179.

Lott L A (1997) The conundrum of patient records. International Journal of Health Care Quality Assurance incorporating Leadership in Health Services (10)2: iv-vi.

Maponya F (2013) No medical records, no treatment. Sowetan 10 April: 6.

Marutha NS (2016) A framework to embed medical records management into the healthcare service delivery in Limpopo Province of South Africa, $\mathrm{PhD}$ Thesis, University of South Africa.

Marutha NS (2011) Records management in support of service delivery in the public health sector of the Limpopo province in South Africa, MINF Thesis, University of South Africa, Pretoria.

Marutha NS and Ngulube P (2012) Electronic records management in the public health sector of the Limpopo province in South Africa. Journal of the South African Society of Archivists 45:39-67.

McLeod J, Childs S and Heaford S (2007) Records management capacity and compliance toolkits: a critical assessment. Records Management Journal (17) 3: 216-232.

Monama T (2013) Patients, staff spells it out to Madonsela: missing files, poor equipment still plague Mankweng. Sowetan, 29 August: 5. 
Moreq2 (2008) Model requirements for the management of electronic records. Available at http://moreq2.eu/attach ments/article/189/MoReq2_typeset_version.pdf (accessed 26 April 2014)

Ndenje-Sichalwe E, Ngulube P and Stilwell C (2011) Managing records as a strategic resource in the government ministries of Tanzania. Information Development 27(4) 264-279.

Nengomasha C (2013) The past, present and future of records and archives management in sub-Saharan Africa. Journal of the South African Society of Archivists 46: 2-11.

Ngoepe M (2017) Archival orthodoxy of post-custodial realities for digital records in South Africa. Archives and Manuscripts 45(1): 31-44.

Ngoepe M (2016) Records management models in the public sector in South Africa: is there a flicker of light at the end of the dark tunnel? Information Development (32)3: $338-353$.

Ngoepe M (2014) Records management models in the public sector in South Africa: is there a flicker of light at the end of the dark tunnel? Information Development. September:1-16.

Ngoepe MS (2012) Fostering a framework to embed the records management function into the auditing process. $\mathrm{PhD}$ Thesis, Pretoria, University of South Africa.

Ngoepe M and Makhubela S (2015) Justice delayed is justice denied. Records Management Journal 25(3): 288-305.

Ngoepe M and Makhura M (2008) Assessing the level of compliance with regard to the Legal Deposit Act: implications on access to South Africa's published heritage. Mousaion (26)2: 98-114.

Ngoepe M and Saurombe A (2016) Provisions for managing and preserving records created in networked environments in the archival legislative frameworks of selected member states of the Southern African Development Community. Archives and Manuscripts (44)1: 24-41.

Ngoepe M and Van der Walt T (2010) A framework for a records management programme: lessons from the Department of Cooperative Governance and Traditional Affairs in South Africa. Mousaion (28)2: 82-106.
Republic of South Africa (1978) Copyright Act, Act No.98 of 1978.

Republic of South Africa (1996) National Archives of South Africa Act, Act No. 43 of 1996.

Republic of South Africa (1999) Public Finance Management Act, Act No.1 of 1999.

Republic of South Africa (2000) Promotion of Access to Information Act, Act No. 2 of 2000.

Republic of South Africa (2001) Limpopo Provincial Archives Act, Act No. 5 of 2001.

Republic of South Africa (2002) Electronic Communication and Transaction Act, Act No. 25 of 2002.

Republic of South Africa (2003) National Health Act, Act No. 61 of 2003.

Republic of South Africa (2010) Protection of State Information Bill, B6-2010.

Republic of South Africa (2013) Protection of Personal Information Act, Act No. 4 of 2013.

\section{About the author}

Dr Ngoako Marutha is a Senior Lecturer in the Department of Information Science at the University of South Africa (UNISA). He also serves as a co-editor for the South African Society of Archivists (SASA) journal and represents SASA for Limpopo region. He previously worked as an information and records manager at Voortrekker hospital, South African Social Security Agency SASSA), St. Rita's Hospital and Limpopo provincial Department of Health. Dr Marutha also worked for the Council for Scientific and Industrial Research (CSIR), Palmer Development Group (PDG), and Vaal University of Technology (VUT), Monash University, and Limpopo Department of Sports, Arts and Culture as a librarian. He hold an advanced certificate in archives and records management (UNISA), BInf (UNIN), BInf HONS (UNIN), Minf (UNISA) and DLit et Phil/PhD (UNISA). He has presented several conference papers and published articles. Contact: Department of Information Science, University of South Africa, Preller Street, Muckleunek, Pretoria, Gauteng Province, South Africa. Tel +2712 4296709 . E-Mail: emarutns@unisa.ac.za. 